Article

\title{
Thymelaea hirsuta and Echinops spinosus: Xerophytic Plants with High Potential for First-Generation Biodiesel Production
}

\author{
Nesma M. Helal ${ }^{1}$, Hesham F. Alharby ${ }^{2}$, Basmah M. Alharbi ${ }^{3}$, Atif. A. Bamagoos ${ }^{2}$ and \\ Ahmed M. Hashim 1,*(1) \\ 1 Botany Department, Faculty of Science, Ain Shams University, Cairo 11865, Egypt; nesmaflax@yahoo.co.uk \\ 2 Department of Biological Sciences, Faculty of Science, King Abdulaziz University, Jeddah 21589, Saudi \\ Arabia; halharby@kau.edu.sa (H.F.A.); abamagoos@kau.edu.sa (A.A.B.) \\ 3 Biology Department, Faculty of Science, Tabuk University, Tabuk 71421, Saudi Arabia; b.alharbi@ut.edu.sa \\ * Correspondence: Hashim-a-m@sci.asu.edu.eg
}

Received: 1 January 2020; Accepted: 31 January 2020; Published: 5 February 2020

check for updates

\begin{abstract}
The negative impacts of fossil fuel on the environment should be replaced by clean and sustainable energy sources worldwide. Therefore, the use of biodiesel as a clean energy source is crucial. Biodiesel is produced from various natural resources through a transesterification process. Considering the importance of this topic, this study focuses on the assessment of oil properties of Thymelaea hirsuta and Echinops spinosus as primary sources for biodiesel production. The two investigated plants were collected from the Western Desert of Egypt. The results showed that the lignocellulosic content was about 57.3 and $79.8 \mathrm{~g} / 100 \mathrm{~g}$ in E. spinosus and 59.1 and $82.8 \mathrm{~g} / 100 \mathrm{~g}$ in $T$. hirsuta, respectively. The two investigated samples showed variable lipid contents (30.2-76.1\%). The GC-MS fatty acid profile characterized seven FAs in E. spinosus and twelf FAs in T. hirsuta. The greatest $\mathrm{CN}$ was calculated in T. hirsuta (379.2) compared to the lowest in E. spinosus (229.9). Furthermore, the values of saponification number (SN) were 27.9 in E. spinosus and 16.07 in T. hirsuta. The value of higher heating value (HHV) was about $47.5 \mathrm{MJ} / \mathrm{kg}$ in E. spinosus and $48.3 \mathrm{MJ} / \mathrm{kg}$ in T. hirsuta. Meanwhile, T. hirsuta exhibited a higher induction period (IP) value $(19.3 \mathrm{~h})$ comparable to that of $E$. spinosus $(4.3 \mathrm{~h})$. The results revealed that both plants are potential sources for biodiesel production according to various international standards for biodiesel production, and this work appears to be one of the first reports regarding such wild xerophytic plants as promising new primary sources for biodiesel production in Egypt.
\end{abstract}

Keywords: biodiesel; lignocellulosic fibers; xerophytes; fatty acid profile; Thymelaea hirsuta and Echinops spinosus

\section{Introduction}

Energy is a key requirement for every country's economic growth. As the world's oil supplies have slowly declined [1,2], suitable alternative fuel sources are urgently needed. Currently, research has focused on biofuel production from various sustainable bio-resources, in particular plants that are not edible [3]. Moreover, the effect of airborne pollutants on human health has become a pressing issue worldwide [4], and biodiesel is a promising solution to this problem. Biodiesel is one of the non-polluting renewable fuels and has received considerable attention [5].

Biodiesel derived from plant-based materials presents several advantages [6]. The use of biodiesel significantly minimizes the emissions of harmful greenhouse gases, aromatic hydrocarbons, and sulfur particles, but it somewhat raises the fuel consumption and decreases the engine power. Even though nitrogen oxide $\left(\mathrm{NO}_{\mathrm{x}}\right)$ emissions are increased in such cases, this can be diminished using exhaust 
gas recirculation [7]. From an environmental point of view, biodiesel is non-toxic, renewable, and biodegradable, which is contrasted by fossil fuels [8,9]. By comparing biodiesel and petro-diesel properties, it has been found that biodiesel produced from bio-resources is one of the outstanding alternatives to present fossil diesel. Biodiesel has supreme physiochemical properties compared to petro-diesel for example, low ash content, low carbon residue, and higher cetane number (a preferable advantage regarding emissions and engine performance) but other properties can be enhanced via blending processes [10]. In addition to this, biodiesel viscosity, density, and oxygen contents are being from the most important factors in engine operation [11,12]. The high viscosity prolongs the time of ignition, decline the efficiency of atomization, lowering injection pressure, and decreases the fuel full combustion. As for the high density, it will instantly affect the mixing of diesel and biodiesel, that leading to stratification of mixed oils [13]. However, regarding to oxygen contents, diesel don't contains oxygen, while biodiesel does. High oxygen contents improves the combustion proccess through raises its temperature and promotes full burning of the fuel, which effectively reducing carbon monoxide (CO), particular molecules (PM), and other harmful exhaust emissions in diesel engines [11,12]. Therefor, Viscosity, density and oxygen contents are important factors that immediately impacts the exhaust properities and combustion performance of an engine.

On the other hand, use of some types of biodiesel instead of petro-diesel may decrease the major performance parameters of compression ignition engines [14]. Generally, the main challenges facing biodiesel production are cost and availability of sustainable raw materials. Therefore, price and availability of raw materials are among the most important factors that must be taken into consideration. In the meantime, the properties of biodiesel depend on the feedstock and its chemical components. Indeed, lignocellulose is considered as the primary biomass fibrous material (e.g., lignin and polysaccharides such as cellulose, hemicellulose, and pectin, which present a promising alternative biofuel) [15]. In general, bioethanol and biodiesel are the two main marketed products for biofuels. Lignocellulosic biomass and non food-oil-seed crops are used for bioethanol production, while plant-produced fatty acid-forming methyl esters (FAME) produce biodiesel [16].

The physiochemical characteristics of biodiesel are mainly based upon fatty acid profile including the fatty acid chain length, unsaturation degree, and the FA composition [17]. Biodiesel generated from unsaturated fatty acids displays oxidative degradation over time [18]. Meanwhile, the oxidation rate of these unsaturated fatty acids is related to both the number and location of double bonds in the carbonic chain. Moreover, oxidation increases peroxide formation and, in turn, increases the cetane number and reduces ignition delay $[19,20]$. Biodiesel quality is determined by several physicochemical properties of fatty acids and the methyl ester composition. Among these properties. cetane number $(\mathrm{CN})$, saponification number (SN), iodine value (IV), degree of unsaturation (DU), cold filter plugging point (CFPP), long chain saturated fatty acids (LCSFs), induction period (IP), and higher heating value (HHV) [21] are the main parameters controlling the fuel quality [22-24]. The production of butanol and ethanol (as gasoline additives) and long-chain hydrocarbones (for diesel additives) from hemicellulose, cellulose, oils and starch are the most abundant sources of renewable fuels obtained from plants. However, lignocellulose and plant oils are very costly for biofuel production $[25,26]$.

Nowadays, vegetable oils such as palm oil, soybean oil, rapeseed oil, and sunflower oil have been intensively studied as a primary source for biodiesel production [14]. Other potential vegetables that are used as feedstock for biodiesel production include desert plants (Balanites aegyptiaca [27]), tobacco (Nicotiana tabacum), rubber trees (Hevea brasiliensis), milkweed (Asclepias syriaca), Ethiopian or Abyssinian mustard (Brassica carinata), false flax (Camelina sativa), cardoon (Cynara cardunculus), sesame (Sesamum indicum), marula (Sclerocara birrea), and jojoba (Simmondsia chinensis) [28-31]. Moreover, many studies have been performed to discover other alternative (relatively cheap) and potential raw materials that aim to reduce biodiesel production cost, such as microbial lipids (Micro-algae, Algae, Fungi, and Yeast), cellular biomass [32,33], brane and rice straw [34,35], and non-edible plant oils [36,37].

As an alternate and possible way to produce biofuel, the steady growth in the use of wild plant oil in Africa and Asia should be concentrated [25,38]. Fossil fuel resources for energy production are 
rare in Egypt, so alternative bio-resources, such as non-edible wild plants, should be used for biodiesel production to meet the increasing demand in energy.

The genus Echinops spinosus (L.) belongs to the family Asteraceae; it is a perennial herb, growing to about $1 \mathrm{~m}$, with erect brownish to reddish stems. It has a few long leaves, 10 to $15 \mathrm{~cm}$ in length, is hairy, arachnoid, and has very long spines [39]. Echinops spinosus is distributed regionally in North Africa and throughout the Sahara, including the Red Sea region and Sinai. Such wild shrubs are naturally adapted to drought conditions and have various medicinal purposes [40].

In addition, Thymelaea hirsuta (L.) Endl. belongs to the family thymelaceae; it is a perennial Mediterranean, evergreen shrub. Moreover, T. hirsuta is a drought-tolerant shrub that grows up to $2 \mathrm{~m}$ high and is considered as one of the psammophytes, with rigid, fibrous stems [41]. It is one of the most common species inhabiting the north coast of Egypt and extends inland approximately $70 \mathrm{~km}$ from the coast [42]. The economic potential of T. hirsuta as a medicinal plant and fiber source was reported by Schmidt and Stavisky [43]. These two xerophytic species have never been reported elsewhere as primary feedstock for biodiesel production.

The two investigated xerophytic plants in this study have been chosen for the following reasons: T. hirsuta has rigid, fibrous stems containing a large amount of cellulose, lignin, and oils [44]. Moreover, T. hirsuta shoots are characterized by a fast ignition time and are used by the Bedouins as solid fuel for energy production [45]. Furthermore, E. spinosus contains an appropriate amount of fatty acids that qualify it to produce biodiesel [46]. Additionally, these two species are widely distributed in arid and semiarid areas in Egypt, grow in soil with low water and nutrient contents, and do not need agricultural fertilizers. Finally, T. hirsuta and E. spinosus are perennial species, which can be cultivated in a sustainable way on non-arable land, especially since there are huge areas of desert land in Egypt that could be used for the cultivation of drought-tolerant plants. Therefore, the production of large quantities of biomass from these plants as raw materials to produce biofuels needs no effort or high cost and is of great economic feasibility. Therefore, this work is aimed at the determination and assessment of energy-generating compounds of Thymelaea hirsuta and Echinops spinosus and their potentiality as primary plant feedstocks for biodiesel production.

\section{Materials and Methods}

\subsection{Plant Material}

The aerial portions (stems and leaves) of two xerophytic plants, Echinops spinosus (Figure 1) and Thymelaea hirsuta (Figure 2), with similar size and age, were collected from their natural habitats (Western Desert of Egypt) in 2019. Botanical identification of the above two plants was confirmed in Ain Shams University, Faculty of Science, Botany Department (the Herbarium section). For two weeks, aerial plant parts have been dried in air under the shade, powdered and then used for analysis. 

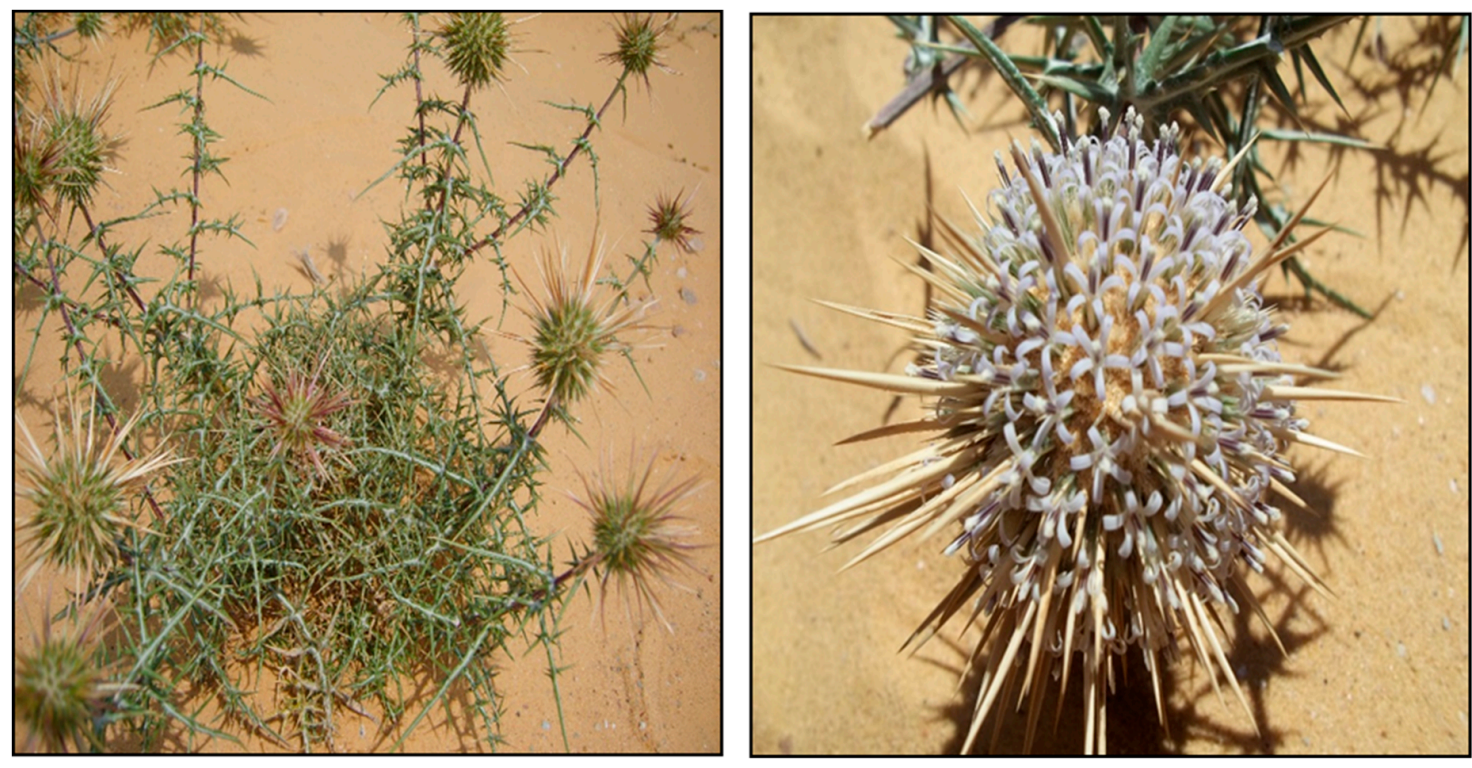

Figure 1. Echinops spinosus at different growth stages in their natural habitat.
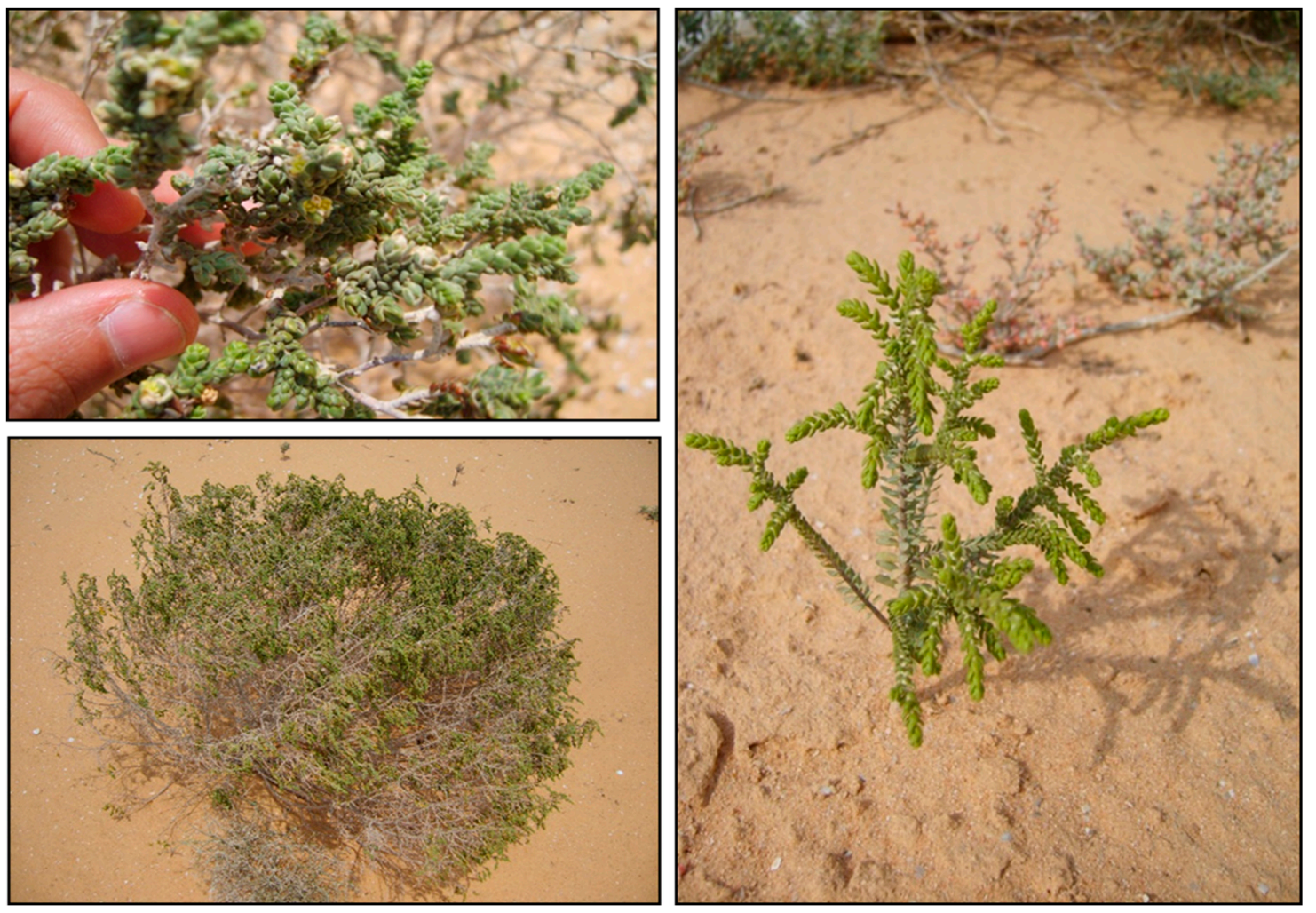

Figure 2. Thymelaea hirsuta at different growth stages in their natural habitat.

\subsection{Methods}

\subsubsection{Estimation of Carbohydrates}

A commonly used method for the extraction of carbohydrates is to boil a known weight of air-dried plant tissue in $10 \mathrm{~mL}$ of $80 \%(v / v)$ ethanol. The extract was filtered, and the filtrate was oven-dried at $60{ }^{\circ} \mathrm{C}$, then dissolved in a known volume of water to be ready for the determination of soluble sugar. The soluble sugar and insoluble sugar contents were measured by the anthrone reagent according to the method of Fairbairn [47]. The concentration of soluble and insoluble sugar was determined finally 
from the standard curve of glucose and calculated as $\mathrm{mg} / \mathrm{g}$ plant tissue. Moreover, the cellulose content was determined by the method described by Reference [48].

\subsubsection{Estimation of Pectin and Lignin}

The fiber quality for pectin and lignin was determined following the methods described by References [49,50], respectively.

\subsubsection{Extraction and Assay of Peroxidase Activity (POX)}

The method adopted for peroxidase extraction was that described by Reference [51]. A dried plant tissue ( $2 \mathrm{~g}$ ) was extracted in $100 \mathrm{mM}$ phosphate buffer ( $\mathrm{pH}$ 6.8). The homogenates were centrifuged at $20,000 \times g$ for $20 \mathrm{~min}$. The supernatant was made to a known volume with the same buffer and was used in enzyme preparation for assaying the activity of certain enzymes. Moreover, POX activity was assayed according to the method of reference [52].

\subsubsection{Estimation of Total Phenols}

Total phenols were extracted and measured according to the method adopted by Reference [53]. In this method, the Folin-Ciocalteau reagent was used to estimate total phenols. The phenolic content was calculated as gallic acid equivalents of gallic acid/g extract on the basis of gallic acid standard curve.

\subsubsection{Lipid Extraction}

The air-dried powder (10 g) was extracted with petroleum ether for $18 \mathrm{~h}$ by using a Soxhlet apparatus [54]. The extract was then transferred quantitatively to a weighed flask, and the solvent was evaporated using an electric fan. The flask was then reweighed, and the difference in weight was equivalent to the weight of total lipids.

\subsubsection{Fatty Acid Composition of oil by GC-MS}

After extraction, the oil underwent to the transesterification process, which was carried out by using methanol and base $(\mathrm{KOH})$ as described by References $[55,56]$. Then, the methyl ester fatty acid composition of yielded oil was analyzed by gas chromatography mass spectrometry (GC-MS) (Figure 3) in accordance with Jun [57] by using an Agilent 7890B GC system coupled to an Agilent 5977A MSD with a capillary column size of $0.6 \mathrm{~m} \times 100 \mu \mathrm{m} \times 0 \mu \mathrm{m}$ (Agilent-Technologies, Sant a Clara, CA, USA). The injector and detector temperatures were set at $250{ }^{\circ} \mathrm{C}$, and the ion source temperature was set at $230^{\circ} \mathrm{C}$. Helium gas was used as carrier gas at a constant flow rate of $1.5 \mathrm{~mL} / \mathrm{min}$. The column temperature was set at $40^{\circ} \mathrm{C}$ for $2 \mathrm{~min}$, then $10^{\circ} \mathrm{C} / \mathrm{min}$ to $180^{\circ} \mathrm{C}$ for $5 \mathrm{~min}$, and then $10^{\circ} \mathrm{C} / \mathrm{min}$ to 250 ${ }^{\circ} \mathrm{C}$ for $10 \mathrm{~min}$. The total GC running time was $38 \mathrm{~min}$. The GC/MS was run in Scan/SIM mode, and the identification of sample components was performed using Agilent Mass Hunter software (NIST14 L). The fatty acids composition was reported as the relative percentage of the total peak area by direct comparison of the retention times and mass spectral data reported in the literature.

\subsection{The Fuel Properties of Biodiesel}

Potential biodiesel fuel properties such as saponification number (SN), iodine value (IV), degree of unsaturation (DU), cetane number (CN), higher heating value (HHV), cold filter plugging point (CFPP), and induction period (IP) were empirically determined according to the method of Reference [58]. 


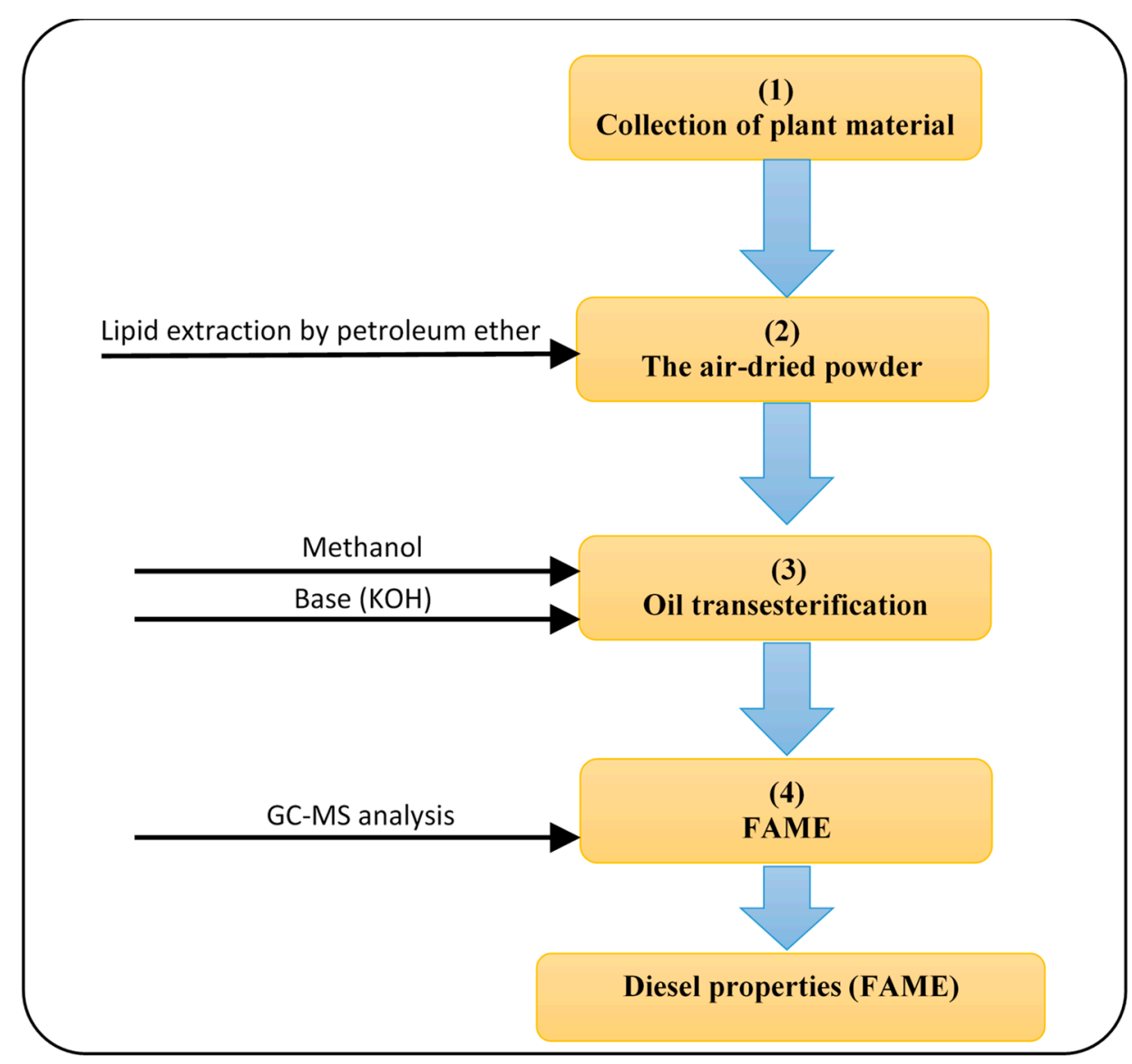

Figure 3. Flow diagram of oil production and biodiesel properties of the two investigated xerophytic plants.

\section{Saponification number (SN) and iodine value (IV)}

The saponification number and iodine value were calculated according to Equations (1) and (2), respectively, from the fatty acid methyl ester composition of oils:

$$
\begin{gathered}
\mathrm{SN}=\sum(560 \times \mathrm{N}) / \mathrm{M} \\
\mathrm{IV}=\sum(254 \times \mathrm{D} \times \mathrm{N}) / \mathrm{M}
\end{gathered}
$$

where $\mathrm{N}$ is the percentage of each fatty acid component, $\mathrm{M}$ is the molecular mass of each fatty acid, and $\mathrm{D}$ is the number of double bonds in each fatty acid [59].

\section{Degree of unsaturation (DU)}

The degree of unsaturation was calculated from Equation (3):

$$
\text { DU }=\text { MUFA }+2 \times \text { PUFA }
$$

where MUFA is the percentage of monounsaturated fatty acids and PUFA is the polyunsaturated fatty acids [60].

\section{Cetane number $(\mathrm{CN})$}

The cetane number was calculated from the following empirical Equation (4) [61]:

$$
\mathrm{CN}=46.3+5458 / \mathrm{SN}-0.225 \times \mathrm{IV} \text {. }
$$




\section{Higher heating value (HHV)}

This parameter was calculated from Equation (5) according to Demirbas [62].

$$
\mathrm{HHV}=49.43-0.041 \times \mathrm{SN}-0.015 \times \mathrm{IV}
$$

\section{Cold filter plugging point (CFPP)}

This was calculated from the long-chain saturated factor (LCSF), which was obtained in Equation (6), with slight modification and post hoc analysis applied in Equation (7) as follows:

$$
\mathrm{LCSF}=(0.1 \mathrm{C} 16)+(0.25 \mathrm{C} 17)+(0.5 \mathrm{C} 18)+(1 \mathrm{C} 20)+(1.5 \mathrm{C} 22)+(2 \mathrm{C} 24)+(2.5 \mathrm{C} 26)+(3 \mathrm{C} 28)+(3.5 \mathrm{C} 30)
$$

where $\mathrm{C} 16, \mathrm{C} 17, \mathrm{C} 18, \mathrm{C} 20, \mathrm{C} 22, \mathrm{C} 24, \mathrm{C} 28$, and $\mathrm{C} 30$ are the amounts of long-chain saturated fatty acids (LCSFAs) (wt.\%) present in each oil [23,63].

$$
\mathrm{CFPP}=3.1417 \times \mathrm{LCSF}-16.477
$$

\section{Induction period (IP)}

This was calculated from the empirical Equation (8) according to Park et al. [64]:

$$
\mathrm{IP}=(117.9295 / \mathrm{X})+2.5905
$$

where $\mathrm{X}$ is the content of PUFA ( $w \mathrm{t} \%)$.

\subsection{Statistical Analysis}

All results were expressed as mean value \pm standard error by using two-way analysis of variance (ANOVA) using IBM Statistical Product and Service Solutions, SPSS Statistics for Windows, Version 21.

\section{Results and Discussion}

Nowadays, there is a great demand for new renewable, sustainable energy sources. Biodiesel production is considered as a potential alternative fuel to reduce the carbon footprint [65].

The major polymer constituents of biomass are cellulose, pectin, and lignin. The variability in lignocellulosic material depends upon the type of biomass species, plant parts, and the abiotic factors [66,67]. The present study found the cellulose content was about $57.3 \mathrm{~g} / 100 \mathrm{~g}$ in E. spinosus, while it reached about $59.1 \mathrm{~g} / 100 \mathrm{~g}$ in $\mathrm{T}$. hirsuta (Figure 4). The high cellulose content of both investigated plants favors their efficiencies for biofuel production. On the other hand, the lignin content was about $79.8 \mathrm{~g} / 100 \mathrm{~g}$ in E. spinosus and $82.8 \mathrm{~g} / 100 \mathrm{~g}$ in T. hirsuta. Lignin can inhibit cellulase activity [68]; therefore, plant species with less lignin in their cell walls are desirable for biofuel production [69]. The pectin contents reached about 37.9 and $33.5 \mathrm{~g} / 100 \mathrm{~g}$ in E. spinosus and T. hirsuta, respectively (Figure 4). Although lignin is not used for conversion to ethanol, it can be converted to other biofuels or used for biopower generation [70]. Moreover, the proper proportion of lignocellulosic constituents in the cell wall is essential in the fermentation and thermo-chemical conversion processes of biofuels [71], and it helps increase oil yield [72]. 


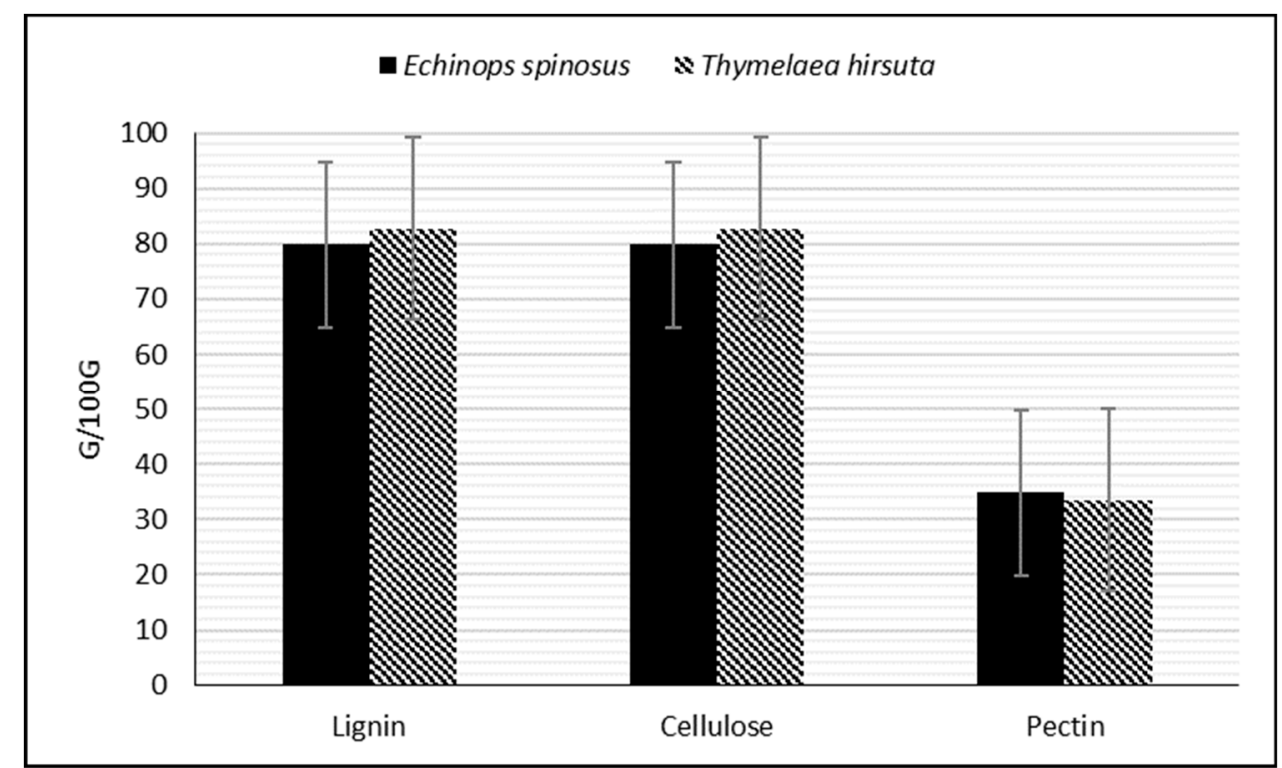

Figure 4. Lignocellulosic analysis in the form of lignin, cellulose, and pectin of Echinops spinosus and Thymelaea hirsuta species. Results are mean of three replicates. The bars on the column show standard error.

In this study, the lignin content in E. spinosus was less than that estimated in T. hirsuta. It is interesting to note here that the peroxidase enzyme showed a variable activity among the two investigated plants E. spinosus and T. hirsuta (Figure 5). The peroxidase activity was higher in E. spinosus (2.62) than that of $T$. hirsuta (1.91). In the present study, lignin content was negatively related to POX activity. Such relation indicated that this enzyme was not involved in lignin synthesis and/or exhibited high oxidative activity in the degradation of lignin dimer [73]. Moreover, the increase in peroxidase activity might be due to the accumulation of certain phenylpropanoids (monomeric units of lignin) resulting in the reduction of structural lignin [74].

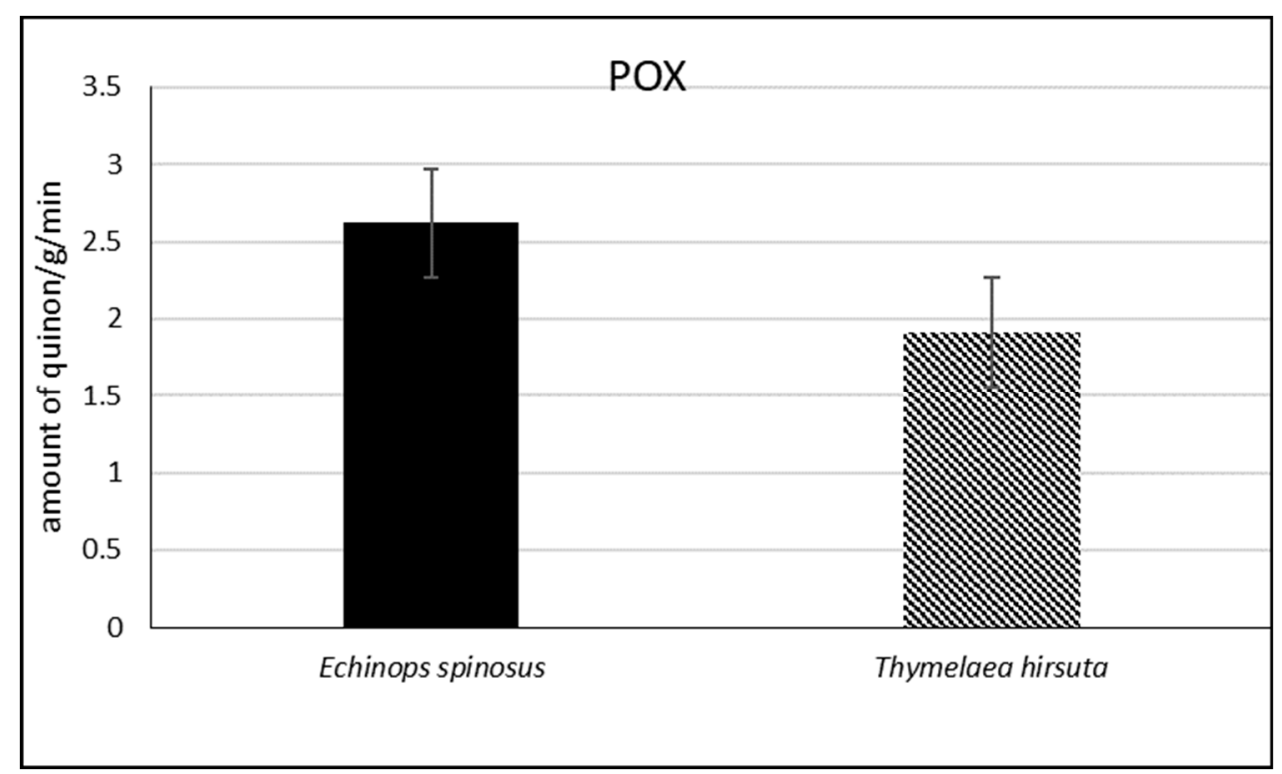

Figure 5. Peroxidase activity of Echinops spinosus and Thymelaea hirsuta species. Results are mean of three replicates. The bars on the column show standard error. 
Indeed, biofuel production is influenced by sugar content [75]. The amount of soluble and insoluble sugars reached about $12.6 \mathrm{mg} / \mathrm{g}$ and $46.9 \mathrm{mg} / \mathrm{g}$ in E. spinosus, while it amounted to be 8.81 $\mathrm{mg} / \mathrm{g}$ and $39.5 \mathrm{mg} / \mathrm{g}$ in $T$. hirsuta, respectively (Figure 6). Such parameters can also be utilized as a source of fermentable sugars used in the production of biofuels [75].

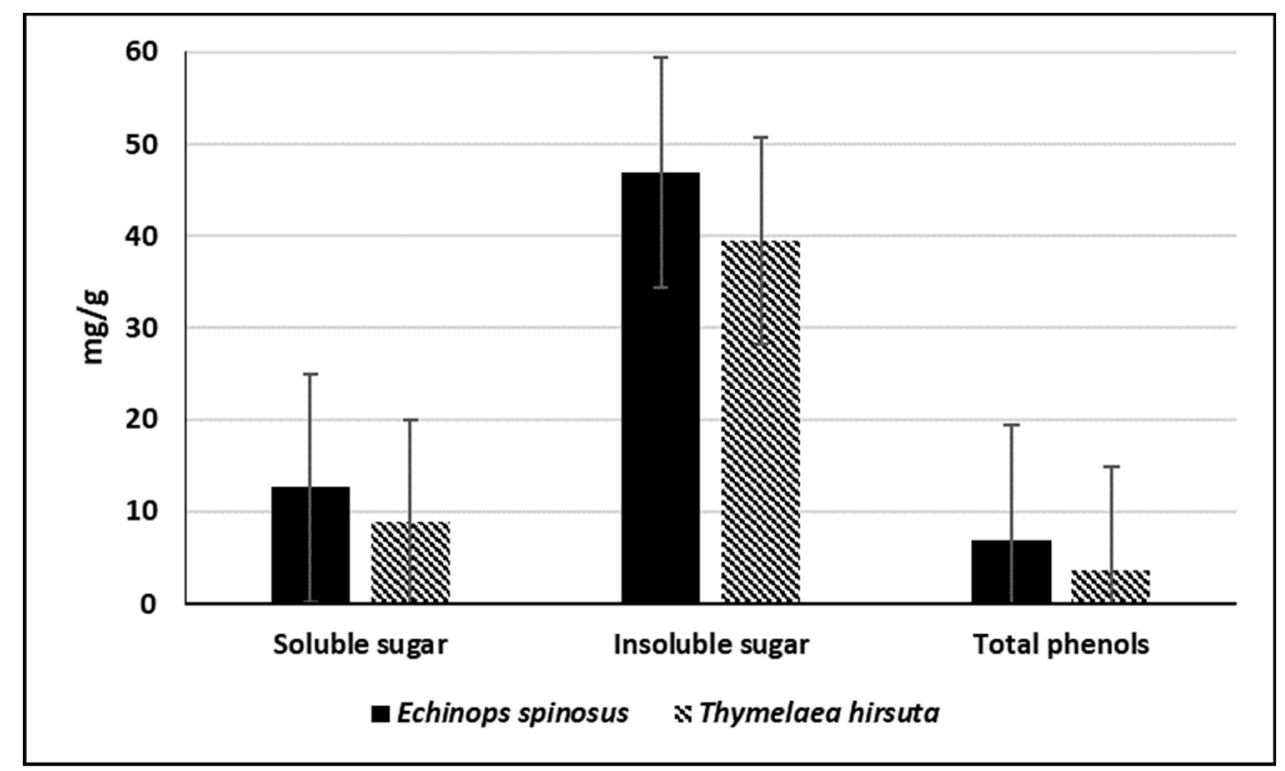

Figure 6. Biochemical analysis as soluble sugar, insoluble sugar, and total phenols of Echinops spinosus and Thymelaea hirsuta species. Results are mean of three replicates. The bars on the column show standard error.

The assayed phenol contents were $6.89 \mathrm{mg} / \mathrm{g}$ in E. spinosus, while they reached about $3.66 \mathrm{mg} / \mathrm{g}$ in T. hirsuta (Figure 6). Natural antioxidants, such as phenolic compounds, protect oils against the oxidation of unsaturated fatty acids [23].

The present data revealed that E. spinosus was one of the best oil producers (Table 1). The oil content expressed as $\mathrm{g} / 100 \mathrm{~g}$ dry weight reached about $76.1 \%$ in E. spinosus and $30.2 \%$ in T. hirsuta (Table 1). In fact, for species selection, the appropriate oil content was about $15 \%$ for biodiesel production [76]. Additionally, our results agree with previous findings on Jatropha spp. [77].

Table 1. The biodiesel properties of Echinops spinosus and Thymelaea hirsuta. Results are mean of three replicates.

\begin{tabular}{|c|c|c|c|c|}
\hline \multirow[b]{2}{*}{ Properties } & \multirow[b]{2}{*}{ Echinops spinosus } & \multirow[b]{2}{*}{ Thymelaea hirsuta } & \multicolumn{2}{|c|}{ Standards } \\
\hline & & & $\begin{array}{c}\text { Europe } \\
\text { (EN14214:2008) }\end{array}$ & $\begin{array}{c}\text { USA } \\
\text { (ASTM D6751) }\end{array}$ \\
\hline Oil content $(\mathrm{g} / \mathbf{1 0 0} \mathrm{g})$ & 76.1 & 30.2 & - & - \\
\hline Cetane number & 229.99 & 379.29 & $>47$ & $>51$ \\
\hline Saponification number (mg/g) & 27.97 & 16.07 & - & - \\
\hline Iodine value ( $\left(\mathrm{I}_{2} / 100 \mathrm{~g}\right)$ & 50.75 & 29.16 & $<120$ & - \\
\hline Cold filter plugging point $\left({ }^{\circ} \mathrm{C}\right)$ & 2.93 & 261.52 & - & - \\
\hline Degree of unsaturation & 142.12 & 16.23 & - & - \\
\hline Induction period (h) & 4.3 & 19.8 & $>3$ & $>6$ \\
\hline $\begin{array}{l}\text { Higher heating value }(\mathrm{MJ} / \mathrm{kg} \text { ) } \\
\text { EN14213 (biodiesel for heating } \\
\text { purposes) }>35.0\end{array}$ & 47.52 & 48.33 & - & - \\
\hline
\end{tabular}

Meanwhile, each plant was characterized by its specific fatty acid profile [78]. The GC-MS fatty acids analysis showed the profile and the percentage of E. spinosus and T. hirsuta extracted crude oil. The oil was characterized seven FAs in E. spinosus and twelve FAs in T. hirsuta (Tables 2 and 3). 
Table 2. Fatty acid profile of Echinops spinosus. Results are mean of three replicates.

\begin{tabular}{ccccc}
\hline PK & RT & \% & Fatty Acids Profile & Molecular Weight (M) \\
\hline & & \multicolumn{4}{c}{ Saturated } \\
\hline 1 & 15.6457 & 0.6515 & Pelargonic acid (C9:0) & 168.236 \\
2 & 12.638 & 11.1106 & Palmitic acid (C16:0) & 270.457 \\
3 & 13.8877 & 13.9789 & Margaric acid (C17:0) & 270.5 \\
4 & 14.5708 & 0.6286 & Cerotic acid (C26:0) & 396.7 \\
\hline & & & Monounsaturated & \\
5 & 12.638 & 0.4791 & Palmitoleic acid (C16:1) & 254.41 \\
6 & 14.8514 & 1.0044 & Gadoleic acid (C20:1) & 310.5 \\
\hline 7 & 13.84 & 70.318 & Linolelaidic acid (C18:2) & 294.47 \\
\hline
\end{tabular}

Table 3. Fatty acid profile of Thymelaea hirsuta. Results are mean of three replicates.

\begin{tabular}{ccccc}
\hline PK & $\mathbf{R T}$ & $\mathbf{\%}$ & Fatty Acids Profile & Molecular Weight (M) \\
\hline & & \multicolumn{4}{c}{ Saturated } \\
\hline $\mathbf{1}$ & 16.2335 & 2.2571 & Caprylic acid (C8:0) & 144.21 \\
$\mathbf{2}$ & 13.9407 & 4.1722 & Pelargonic acid (C9:0) & 168.236 \\
$\mathbf{3}$ & 13.2523 & 0.5486 & Undecanoic acid (C11:0) & 170.29 \\
$\mathbf{4}$ & 12.9822 & 18.9054 & Palmitic acid (C16:0) & 270.457 \\
$\mathbf{5}$ & 17.1179 & 5.8693 & Stearic acid (C18:0) & 284.5 \\
$\mathbf{6}$ & 14.825 & 22.6803 & Arachidic acid (C20:0) & 326.565 \\
$\mathbf{7}$ & 15.6352 & 28.0823 & Behenic acid (C22:0) & 354.619 \\
$\mathbf{8}$ & 16.4189 & 6.3399 & Lignoceric acid (C24:0) & 382.673 \\
$\mathbf{9}$ & 16.9537 & 1.7649 & Melissic acid (C30:0) & 466.835 \\
\hline & & \multicolumn{5}{c}{ Monounsaturated } \\
\hline $\mathbf{1 0}$ & 15.8205 & 1.6744 & Oleic acid (C18:1) & 282.5 \\
$\mathbf{1 1}$ & 17.3455 & 0.8553 & Erucic acid (C22:1) & 338.6 \\
\hline & & \multicolumn{5}{c}{ Polyunsaturated } \\
\hline $\mathbf{1 2}$ & 13.8454 & 6.8504 & Linolelaidic acid (C18:2) & 294.47 \\
\hline
\end{tabular}

It is interesting to note here that E. spinosus was a rich source of polyunsaturated fatty acids (PUFAs) such as linolelaidic acid (C18:2, about 70.31\%), followed by margaric acid (C17:0, 13.97\%) and palmitic acid (C16:0,11.11\%). At the same time, monounsaturated fatty acids MUFAs such as palmitoleic acid (C16:1, 0.47\%) and gadoleic acid (C20:1, 1.00\%) were abundantly found in E. spinosus, along with palmitic acid. Additionally, behenic acid (C22:0, 28.08\%), arachidic acid (C20:0, 22.68\%), palmitic acid (C16:0, 18.9\%), and stearic acid $(\mathrm{C} 18: 0,5.86)$ were the four major components of FA detected in T. hirsuta oil (Table 3). Other FAs such as lignoceric acid (C24:0), undecanoic acid (C11:0), and melissic acid (C30:0) were also differentially detected in trace amounts in T. hirsuta oil. Other MUFAs such as oleic acid (C18:1, 1.67\%) and erucic acid (C22:1, 0.85\%) were also detected. On the other hand, the PUFA linolelaidic unsaturated fatty acid (C18:2, about $6.85 \%)$ also was detected in the oil extracted from T. hirsuta (Table 3).

The changes in fatty acid composition in plant membranes are critical for the plant to adapt to desert conditions $[79,80]$. The oil composition of the investigated plants inhabiting an arid habitat is greatly influenced by the environmental conditions and genetic factors [81]. In addition, the profiles of the fatty acid methyl ester determine the properties of biofuel [82]. The composition of fatty acids in the vegetable oil determines the cetane number of the produced biodiesel [82]. Indeed, the cetane number (CN) of biodiesel, which measures the ignition and combustion quality of the fuel, is the primary factor affecting the fuel properties. Higher $\mathrm{CN}$ improves the ignition and delays the combustion of fuel. In this study, CN values were about 229.9 in E. spinosus, which was lower than that in T. hirsuta (379.2; 
Table 1). These results were relevant to the United States (ASTM D 6751) and Europe (EN 14214:2008) biodiesel standards, who point out that the appropriate values are $>51$ and $>47$ respectively [83]. In addition, Iodine value (IV) is the most common indicator used to determine the quality of fuel [84]. The values of IV reached about 50.75 in E. spinosus and 29.16 in T. hirsuta (Table 1). Generally, standards of biodiesel by EN14214 indicate the value of iodine $<115 \mathrm{~g}$ I2/100 $\mathrm{g}$ [83], while iodine $<120$ is mentioned for European standards of biodiesel. It was recorded that lower values of iodine will encompass solidification of FAME at ambient temperature. However, in biodiesel production the fatty acid methyl ester formula desires unsaturated FAMEs, as they prevent biodiesel solidify [85]. Consequently, $E$. spinosus oil is better than T. hirsuta as a source of raw material for biodiesel production because of its higher iodine content, concomitant with the increase in the number of unsaturated double bonds, thereby reducing the oil viscosity [86]. The relatively observed low iodine values might be attributed to the high values of temperature in a desert habitat, which stimulate the occurrence of saturated fats instead of unsaturated ones [87]. The IV of FAMEs exhibited a negative relation with CN (Table 1), which reached about $50.75 \mathrm{~g} \mathrm{I}_{2} / 100 \mathrm{~g}$ and $29.16 \mathrm{~g} \mathrm{I}_{2} / 100 \mathrm{~g}$ in E. spinosus and $T$. hirsuta, respectively. These xerophytic oils exhibit values that are competitive with some traditional vegetable oils used for biodiesel production such as sunflower, soybean, and corn [88]. The high CN value attained in T. hirsuta matched the low IV as compared with those in E. spinosus (Table 1). The results in this study were aligned with the results reported by [89] in palm oil. The current results follow the biodiesel standards in Europe (EN 14214), which indicate a value of iodine $<120$. Meanwhile, low IVs in unsaturated FAMEs [90] prevent oxygen peroxide activity and solidification at ambient temperature, which is desirable for biodiesel quality $[59,83]$. Furthermore, the degree of unsaturation (DU) amounted to be 142.1 and 16.2 in E. spinosus and T. hirsuta, respectively (Table 1). The unsaturated FAMEs are oxidatively unstable because fatty acids react quickly with oxygen double bonds. Moreover, DU significantly affects long-term storage capabilities [91]. The values of the saponification number (SN) in both investigated plants were 27.9 in E. spinosus and 16.07 in T. hirsuta (Table 1). The SNs in this study were lower than those recorded in Jatropha curcas [92]. This biodiesel had highly saturated FAMEs (at most C14:0 and C16:0) and a high saponification value [93]. It was reported that the $\mathrm{SN}$ is related to IV; thus, a higher SN value improves the stability of biodiesel [16].

The value of the cold filter plugging point (CFPP) in T. hirsuta (261.5) was higher than the value recorded in E. spinosus (2.93) (Table 1). Our results follow Park et al. [64], who reported that CFPP values increased concomitantly with the percentage of oil saturation. However, it is arduous to set up enough ranges for CFPP values because of the seasonal temperature variability worldwide [24].

Furthermore, higher heating value (HHV) is a parameter that plays an essential role in determining the quality of biofuels. The presented data showed that HHV reached about $47.5 \mathrm{MJ} / \mathrm{kg}$ in E. spinosus and $48.3 \mathrm{MJ} / \mathrm{kg}$ in T. hirsuta (Table 1). Such data indicated that the values of both tested plants exceeded the limit set (EN14213 (>35.0) standard) for this criterion (Table 1). Such results are parallel to other ones in tropical plants $[90,94]$. Additionally, the results in this study had higher values of HHV than those obtained from corn, cotton seed, and Jatropha curcas [88]. Moreover, such results are desirable properties for biodiesel energy, since the lower heating value of biodiesel is known to decrease the engine power.

The induction period (IP) evaluates the instabilities of physicochemical and thermal biofuel properties, which, in turn, increases its oxidation [95]. In this study, T. hirsuta exhibited a higher IP value $(19.3 \mathrm{~h}$ ) compared to that of E. spinosus (4.3 h) (Table 1). The USA ASTMD6751 and European standards of biodiesel expressed induction periods (at $110^{\circ} \mathrm{C}$ ) of $>3 \mathrm{~h}$ and $>6 \mathrm{~h}$, respectively [24]. Furthermore, the induction period improves linearly for natural antioxidants such as vitamins as well as phenolic compounds. These antioxidants slow down the rate of oxidation of biofuel [96].

\section{Conclusions}

We must face the energy demands of the growing population in our countries. Therefore, providing renewable resources is essential. It was shown in this study that two drought-tolerant plants, 
subjected to many abiotic stresses (i.e., drought and salinity) and biotic stresses (i.e., overgrazing and over collection), could be cultivated in a sustainable way on marginal and non-arable lands of Egypt. The yields will be not as high as when grown on arable land, but arable land should be reserved for the cultivation of food.

In conclusion, the data on biodiesel properties obtained using empirical equations for both Echinops spinosus and Thymelaea hirsuta species based on their FAMEs profile exhibit that both investigated species meet the norms required to be a diesel substitute, and they have enough oil content of moderately long-chain fatty acids with a high degree of unsaturation (DU). Oil of these species characterized by a high cetan number $(\mathrm{CN})$, that improves the ignition and delays the combustion of fuel. In addition, the higher saponification values (SN) along with higher iodine values (IV) will improves the stability of biodiesel.

To summarize, the findings from the preliminary study carried out in this research show that the two xerophytic species investigated are a hopeful, sustainable and potential primary feedstock for future production of biodiesel.

Author Contributions: Conceptualization, A.M.H., and N.M.H.; methodology, N.M.H., A.M.H., B.M.A., H.F.A., and A.A.B.; validation N.M.H., A.M.H., B.M.A., H.F.A., and A.A.B.; formal analysis, N.M.H., A.M.H., B.M.A., H.F.A., and A.A.B.; resources, N.M.H., A.M.H., B.M.A., H.F.A., and A.A.B.; data curation, N.M.H., A.M.H., B.M.A., H.F.A., and A.A.B.; writing-original draft preparation, N.M.H., A.M.H., B.M.A., H.F.A., and A.A.B.; writing-review and editing, N.M.H., A.M.H., B.M.A., H.F.A., and A.A.B. All authors have read and agreed to the published version of the manuscript.

Funding: Deanship of Scientific Research, King Abdulaziz University, Jeddah, Kingdom of Saudi Arabia.

Acknowledgments: This project was funded by the Deanship of Scientific Research (DSR), King Abdulaziz University, Jeddah, under grant no. (D-478-130-1441). The authors, therefore, acknowledge with thanks DSR technical and financial support.

Conflicts of Interest: The authors declare no conflicts of interest.

\section{References}

1. Longwell, H.J. The Future of the Oil and Gas Industry. Word Energy 2002, 5, 5.

2. Tsoskounoglou, M.; Ayerides, G.; Tritopoulou, E. The end of cheap oil: Current status and prospects. Energy Policy 2008, 36, 3797-3806. [CrossRef]

3. Chhetri, A.B.; Tango, M.S.; Budge, S.M.; Watts, K.C.; Islam, M.R. Non-edible plant oils as new sources for biodiesel production. Int. J. Mol. Sci. 2008, 9, 169-180. [CrossRef] [PubMed]

4. Soliman, M.; Alhaithloul, H.A.; Hakeem, K.R.; Alharbi, B.M.; El-Esawi, M.; Elkelish, A. Exogenous Nitric Oxide Mitigates Nickel-Induced Oxidative Damage in Eggplant by Upregulating Antioxidants, Osmolyte Metabolism, and Glyoxalase Systems. Plants 2019, 8, 562. [CrossRef] [PubMed]

5. Ranganathan, S.V.; Narasimhan, S.L.; Muthukumar, K. An overview of enzymatic production of biodiesel. Bioresour. Technol. 2008, 99, 3975-3981. [CrossRef] [PubMed]

6. Sarbolouki, M.N.; Moacanin, J. Chemicals from biomass-The U.S. prospects for the turn of the century. Sol. Energy 1980, 25, 303-315. [CrossRef]

7. Mahmudul, H.M.; Hagos, F.Y.; Mamat, R.; Adam, A.A.; Ishak, W.F.W.; Alenezi, R. Production, characterization and performance of biodiesel as an alternative fuel in diesel engines-A review. Renew. Sustain. Energy Rev. 2017, 72, 497-509. [CrossRef]

8. Singh, S.P.; Singh, D. Biodiesel production through the use of different sources and characterization of oils and their esters as the substitute of diesel: A review. Renew. Sustain. Energy Rev. 2010, 14, 200-216. [CrossRef]

9. Vasudevan, P.T.; Briggs, M. Biodiesel production—Current state of the art and challenges. J. Ind. Microbiol. Biotechnol. 2008, 35, 421. [CrossRef]

10. Demirbas, A. Progress and recent trends in biodiesel fuels. Energy Convers. Manag. 2009, 50, 14-34. [CrossRef]

11. Ge, J.C.; Yoon, S.K.; Choi, N.J. Using Canola Oil Biodiesel as an Alternative Fuel in Diesel Engines: A Review. Appl. Sci. 2017, 7, 881. [CrossRef] 
12. Ge, J.C.; Kim, H.Y.; Yoon, S.K.; Choi, N.J. Optimization of palm oil biodiesel blends and engine operating parameters to improve performance and PM morphology in a common rail direct injection diesel engine. Fuel 2020, 260, 116326. [CrossRef]

13. Tesfa, B.; Mishra, R.; Gu, F.; Powles, N. Prediction models for density and viscosity of biodiesel and their effects on fuel supply system in CI engines. Renew. Energy 2010, 35, 2752-2760. [CrossRef]

14. Sajjadi, B.; Raman, A.A.A.; Arandiyan, H. A comprehensive review on properties of edible and non-edible vegetable oil-based biodiesel: Composition, specifications and prediction models. Renew. Sustain. Energy Rev. 2016, 63, 62-92. [CrossRef]

15. Kuhad, R.C.; Singh, A. Lignocellulose Biotechnology: Current and Future Prospects. Crit. Rev. Biotechnol. 1993, 13, 151-172. [CrossRef]

16. Patel, A.; Arora, N.; Pruthi, V.; Pruthi, P.A. A novel rapid ultrasonication-microwave treatment for total lipid extraction from wet oleaginous yeast biomass for sustainable biodiesel production. Ultrason. Sonochem. 2019, 51, 504-516. [CrossRef]

17. Aransiola, E.F.; Ojumu, T.V.; Oyekola, O.O.; Madzimbamuto, T.F.; Ikhu-Omoregbe, D.I.O. A review of current technology for biodiesel production: State of the art. Biomass Bioenergy 2014, 61, 276-297. [CrossRef]

18. Yang, Z.; Hollebone, B.P.; Wang, Z.; Yang, C.; Landriault, M. Factors affecting oxidation stability of commercially available biodiesel products. Fuel Process. Technol. 2013, 106, 366-375. [CrossRef]

19. Dunn, R.O. Effect of oxidation under accelerated conditions on fuel properties of methyl soyate (biodiesel). J. Am. Oil Chem. Soc. 2002, 79, 915-920. [CrossRef]

20. Elkelish, A.A.; Soliman, M.H.; Alhaithloul, H.A.; El-Esawi, M.A. Selenium protects wheat seedlings against salt stress-mediated oxidative damage by up-regulating antioxidants and osmolytes metabolism. Plant Physiol. Biochem. 2019. [CrossRef]

21. Ramírez-Verduzco, L.F.; Rodríguez-Rodríguez, J.E.; del Jaramillo-Jacob, A.R. Predicting cetane number, kinematic viscosity, density and higher heating value of biodiesel from its fatty acid methyl ester composition. Fuel 2012, 91, 102-111. [CrossRef]

22. Demirbas, A. Comparison of transesterification methods for production of biodiesel from vegetable oils and fats. Energy Convers. Manag. 2008, 49, 125-130. [CrossRef]

23. Górnaś, P.; Rudzińska, M. Seeds recovered from industry by-products of nine fruit species with a high potential utility as a source of unconventional oil for biodiesel and cosmetic and pharmaceutical sectors. Ind. Crops Prod. 2016, 83, 329-338. [CrossRef]

24. Hoekman, S.K.; Broch, A.; Robbins, C.; Ceniceros, E.; Natarajan, M. Review of biodiesel composition, properties, and specifications. Renew. Sustain. Energy Rev. 2012, 16, 143-169. [CrossRef]

25. Balat, M. Production of bioethanol from lignocellulosic materials via the biochemical pathway: A review. Energy Convers. Manag. 2011, 52, 858-875. [CrossRef]

26. Chapagain, B.P.; Yehoshua, Y.; Wiesman, Z. Desert date (Balanites aegyptiaca) as an arid lands sustainable bioresource for biodiesel. Bioresour. Technol. 2009, 100, 1221-1226. [CrossRef]

27. Bambara, L.D.F.; Sawadogo, M.; Roy, D.; Anciaux, D.; Blin, J.; Ouiminga, S.K. Biofuel from Balanites aegyptiaca: Optimization of the Feedstock Supply Chain. Sustainability 2018, 10, 4501. [CrossRef]

28. Moser, B.R. Biodiesel Production, Properties, and Feedstocks. Vitro Cell. Dev. Biol. Plant 2009, 45, $229-266$. [CrossRef]

29. Elkelish, A.A.; Alnusaire, T.S.; Soliman, M.H.; Gowayed, S.; Senousy, H.H.; Fahad, S. Calcium availability regulates antioxidant system, physio-biochemical activities and alleviates salinity stress mediated oxidative damage in soybean seedlings. J. Appl. Bot. Food Qual. 2019, 258-266.

30. Elkelish, A.A.; Alhaithloul, H.A.S.; Qari, S.H.; Soliman, M.H.; Hasanuzzaman, M. Pretreatment with Trichoderma harzianum alleviates waterlogging-induced growth alterations in tomato seedlings by modulating physiological, biochemical, and molecular mechanisms. Environ. Exp. Bot. 2019, 103946. [CrossRef]

31. Elkeilsh, A.; Awad, Y.M.; Soliman, M.H.; Abu-Elsaoud, A.; Abdelhamid, M.T.; El-Metwally, I.M. Exogenous application of $\beta$-sitosterol mediated growth and yield improvement in water-stressed wheat (Triticum aestivum) involves up-regulated antioxidant system. J. Plant Res. 2019, 132, 881-901. [CrossRef]

32. Huang, J.; Xia, J.; Jiang, W.; Li, Y.; Li, J. Biodiesel production from microalgae oil catalyzed by a recombinant lipase. Bioresour. Technol. 2015, 180, 47-53. [CrossRef] 
33. Wahlen, B.D.; Morgan, M.R.; McCurdy, A.T.; Willis, R.M.; Morgan, M.D.; Dye, D.J.; Bugbee, B.; Wood, B.D.; Seefeldt, L.C. Biodiesel from Microalgae, Yeast, and Bacteria: Engine Performance and Exhaust Emissions. Energy Fuels 2013, 27, 220-228. [CrossRef]

34. El Boulifi, N.; Bouaid, A.; Martinez, M.; Aracil, J. Optimization and oxidative stability of biodiesel production from rice bran oil. Renew. Energy 2013, 53, 141-147. [CrossRef]

35. Zheng, L.; Hou, Y.; Li, W.; Yang, S.; Li, Q.; Yu, Z. Biodiesel production from rice straw and restaurant waste employing black soldier fly assisted by microbes. Energy 2012, 47, 225-229. [CrossRef]

36. Fadhil, A.B.; Aziz, A.M.; Al-Tamer, M.H. Biodiesel production from Silybum marianum L. seed oil with high FFA content using sulfonated carbon catalyst for esterification and base catalyst for transesterification. Energy Convers. Manag. 2016, 108, 255-265. [CrossRef]

37. Lee, H.V.; Juan, J.C.; Taufiq-Yap, Y.H. Preparation and application of binary acid-base CaO-La2O3 catalyst for biodiesel production. Renew. Energy 2015, 74, 124-132. [CrossRef]

38. Kansedo, J.; Lee, K.T.; Bhatia, S. Cerbera odollam (sea mango) oil as a promising non-edible feedstock for biodiesel production. Fuel 2009, 88, 1148-1150. [CrossRef]

39. Boulos, L. Medicinal Plants of North Africa; Reference Publications, Inc.: Algonac, MI, USA, 1983.

40. Boumaraf, M.; Benyahia, S.; Mekkiou, R.; Benayache, S.; Benayache, F. Flavonoids from Ethyl Acetate Extract of Echinops spinosus (Asteraceae). 2016. Available online: https://www.researchgate.net/publication/304970181_ Flavonoids_from_ethyl_acetate_extract_of_Echinops_spinosus_Asteraceae (accessed on 1 January 2020).

41. Zahran, M.A.; El-Amier, Y.A. Ecology and establishment of fiber producing taxa naturally growing in the Egyptian deserts. Egypt. J. Basic Appl. Sci. 2014, 1, 144-150. [CrossRef]

42. Shaltout, K.H.; Ayyad, M.A. Structure and standing crop of EgyptianThymelaea hirsuta populations. Vegetatio 1988, 74, 137-142. [CrossRef]

43. Schmidt, J.; Stavisky, N. Uses ofThymelaea hirsuta (Mitnan) with emphasis on hand papermaking. Econ. Bot. 1983, 37, 310-321. [CrossRef]

44. Kadri, A.; Zarai, Z.; Chobba, I.B.; Gharsallah, N.; Damak, M.; Békir, A. Chemical composition and in vitro antioxidant activities of Thymelaea hirsuta L. essential oil from Tunisia. Afr. J. Biotechnol. 2011, 10, 2930-2935.

45. Zahran, M.; Boulos, S.T. Potentialities of the fiber plants of the Egyptian flora in national economy. II Thymelaea hirsuta. Bull. Fac. Sci. Mansoura Univ. 1973, 1, 77-87.

46. Bitew, H.; Hymete, A. The Genus Echinops: Phytochemistry and Biological Activities: A Review. Front. Pharmacol. 2019, 10, 1234. [CrossRef]

47. Maness, N. Extraction and Analysis of Soluble Carbohydrates. In Plant Stress Tolerance; Sunkar, R., Ed.; Humana Press: Totowa, NJ, USA, 2010; Volume 639, pp. 341-370. ISBN 978-1-60761-701-3.

48. Jenkins, S.H. The determination of cellulose in straws. Biochem. J. 1930, 24, 1428-1432. [CrossRef]

49. Nanji, D.R.; Norman, A.G. Studies on pectin. Part II: The estimation of the individual pectic substances in nature. Biochem. J. 1928, 22, 596-604.

50. Ritter, G.J.; Seborg, R.M.; Mitchell, R.L. Factors Affecting Quantitative Determination of Lignin by 72 Per Cent Sulfuric Acid Method. Ind. Eng. Chem. Anal. Ed. 1932, 4, 202-204. [CrossRef]

51. Mukherjee, S.P.; Choudhuri, M.A. Implications of water stress-induced changes in the levels of endogenous ascorbic acid and hydrogen peroxide in Vigna seedlings. Physiol. Plant. 1983, 58, 166-170. [CrossRef]

52. Bradford, M.M. A rapid and sensitive method for the quantitation of microgram quantities of protein utilizing the principle of protein-dye binding. Anal. Biochem. 1976, 72, 248-254. [CrossRef]

53. Malik, C.P.; Singh, M.B. Plant Enzymology and Histo-Enzymology: A Text Manual; Kalyani Publishers: New Delhi, India, 1980.

54. Official Methods of Analysis of AOAC International, 20th ed.; Latimer, G.W.; AOAC International (Eds.) AOAC International: Gaithersburg, MD, USA, 2016; ISBN 978-0-935584-87-5.

55. Karaosmanoğlu, F.; Cığızoğlu, K.B.; Tüter, M.; Ertekin, S. Investigation of the Refining Step of Biodiesel Production. Energy Fuels 1996, 10, 890-895. [CrossRef]

56. Lang, X.; Dalai, A.K.; Bakhshi, N.N.; Reaney, M.J.; Hertz, P.B. Preparation and characterization of bio-diesels from various bio-oils. Bioresour. Technol. 2001, 80, 53-62. [CrossRef]

57. Jiang, J.; Jia, X. Profiling of Fatty Acids Composition in Suet Oil Based on GC-EI-qMS and Chemometrics Analysis. Int. J. Mol. Sci. 2015, 16, 2864-2878. [CrossRef] 
58. Francisco, É.C.; Neves, D.B.; Jacob-Lopes, E.; Franco, T.T. Microalgae as feedstock for biodiesel production: Carbon dioxide sequestration, lipid production and biofuel quality. J. Chem. Technol. Biotechnol. 2010, 85, 395-403. [CrossRef]

59. Kalayasiri, P.; Jeyashoke, N.; Krisnangkura, K. Survey of seed oils for use as diesel fuels. J. Am. Oil Chem. Soc. 1996, 73, 471-474. [CrossRef]

60. Degirolamo, C.; Rudel, L.L. Dietary Monounsaturated Fatty Acids Appear Not to Provide Cardioprotection. Curr. Atheroscler. Rep. 2010, 12, 391-396. [CrossRef] [PubMed]

61. Krisnangkura, K. A simple method for estimation of cetane index of vegetable oil methyl esters. J. Am. Oil Chem. Soc. 1986, 63, 552-553. [CrossRef]

62. Demirbas, A. Biofuels sources, biofuel policy, biofuel economy and global biofuel projections. Energy Convers. Manag. 2008, 49, 2106-2116. [CrossRef]

63. Ramos, M.J.; Fernández, C.M.; Casas, A.; Rodríguez, L.; Pérez, Á. Influence of fatty acid composition of raw materials on biodiesel properties. Bioresour. Technol. 2009, 100, 261-268. [CrossRef]

64. Park, J.-Y.; Kim, D.-K.; Lee, J.-P.; Park, S.-C.; Kim, Y.-J.; Lee, J.-S. Blending effects of biodiesels on oxidation stability and low temperature flow properties. Bioresour. Technol. 2008, 99, 1196-1203. [CrossRef]

65. Kumar, M.; Sharma, M.P. Selection of potential oils for biodiesel production. Renew. Sustain. Energy Rev. 2016, 56, 1129-1138. [CrossRef]

66. Mendu, V.; Harman-Ware, A.E.; Crocker, M.; Jae, J.; Stork, J.; Morton, S.; Placido, A.; Huber, G.; DeBolt, S. Identification and thermochemical analysis of high-lignin feedstocks for biofuel and biochemical production. Biotechnol. Biofuels 2011, 4, 43. [CrossRef]

67. Thakur, V.K.; Thakur, M.K. Recent advances in green hydrogels from lignin: A review. Int. J. Biol. Macromol. 2015, 72, 834-847. [CrossRef] [PubMed]

68. Chen, X.; Li, Z.; Zhang, X.; Hu, F.; Ryu, D.D.Y.; Bao, J. Screening of Oleaginous Yeast Strains Tolerant to Lignocellulose Degradation Compounds. Appl. Biochem. Biotechnol. 2009, 159, 591-604. [CrossRef] [PubMed]

69. Ding, S.-Y.; Liu, Y.-S.; Zeng, Y.; Himmel, M.E.; Baker, J.O.; Bayer, E.A. How does plant cell wall nanoscale architecture correlate with enzymatic digestibility? Science 2012, 338, 1055-1060. [CrossRef] [PubMed]

70. Oasmaa, A.; Alén, R.; Meier, D. Catalytic hydrotreatment of some technical lignins. Bioresour. Technol. 1993, 45, 189-194. [CrossRef]

71. Anker, Y.; Nakonechny, F.; Niazov, B.; Lugovskoy, S.; Nisnevitch, M. Biofuel Production by Fermentation of Water Plants and Agricultural Lignocellulosic by-Products. MATEC Web Conf. 2016, 70, 12005. [CrossRef]

72. Fahmi, R.; Bridgwater, A.V.; Donnison, I.; Yates, N.; Jones, J.M. The effect of lignin and inorganic species in biomass on pyrolysis oil yields, quality and stability. Fuel 2008, 87, 1230-1240. [CrossRef]

73. Yang, J.; Gao, T.; Zhang, Y.; Wang, S.; Li, H.; Li, S.; Wang, S. Degradation of the phenolic $\beta$-ether lignin model dimer and dyes by dye-decolorizing peroxidase from Bacillus amyloliquefaciens. Biotechnol. Lett. 2019, 41, 1015-1021. [CrossRef]

74. Alvarez, S.; Marsh, E.L.; Schroeder, S.G.; Schachtman, D.P. Metabolomic and proteomic changes in the xylem sap of maize under drought. Plant Cell Environ. 2008, 31, 325-340. [CrossRef]

75. Macrelli, S.; Galbe, M.; Wallberg, O. Effects of production and market factors on ethanol profitability for an integrated first and second generation ethanol plant using the whole sugarcane as feedstock. Biotechnol. Biofuels 2014, 7, 26. [CrossRef]

76. Moser, B.R.; Vaughn, S.F. Coriander seed oil methyl esters as biodiesel fuel: Unique fatty acid composition and excellent oxidative stability. Biomass Bioenergy 2010, 34, 550-558. [CrossRef]

77. de Oliveira, J.S.; Leite, P.M.; de Souza, L.B.; Mello, V.M.; Silva, E.C.; Rubim, J.C.; Meneghetti, S.M.P.; Suarez, P.A.Z. Characteristics and composition of Jatropha gossypiifoliaand Jatropha curcas L. oils and application for biodiesel production. Biomass Bioenergy 2009, 33, 449-453. [CrossRef]

78. Mishra, A.; Patel, M.K.; Jha, B. Non-targeted metabolomics and scavenging activity of reactive oxygen species reveal the potential of Salicornia brachiata as a functional food. J. Funct. Foods 2015, 13, 21-31. [CrossRef]

79. Navari-Izzo, F.; Milone, M.T.A.; Quartacci, M.F.; Pinzino, C. Metabolic changes in wheat plants subjected to a water-deficit stress programme. Plant Sci. 1993, 92, 151-157. [CrossRef]

80. Yordanov, I.; Velikova, V.; Tsonev, T. Plant Responses to Drought, Acclimation, and Stress Tolerance. Photosynthetica 2000, 38, 171-186. [CrossRef]

81. Bamgboye, A.I.; Hansen, A.C. Prediction of cetane number of biodiesel fuel from the fatty acid methyl ester (FAME) composition. Int. Agrophys. 2008, 22, 21-29. 
82. Zahan, K.; Kano, M. Biodiesel Production from Palm Oil, Its By-Products, and Mill Effluent: A Review. Energies 2018, 11, 2132. [CrossRef]

83. Muthu, H.; SathyaSelvabala, V.; Varathachary, T.K.; Kirupha Selvaraj, D.; Nandagopal, J.; Subramanian, S. Synthesis of biodiesel from Neem oil using sulfated zirconia via tranesterification. Braz. J. Chem. Eng. 2010, 27, 601-608. [CrossRef]

84. Patel, A.; Arora, N.; Mehtani, J.; Pruthi, V.; Pruthi, P.A. Assessment of fuel properties on the basis of fatty acid profiles of oleaginous yeast for potential biodiesel production. Renew. Sustain. Energy Rev. 2017, 77, 604-616. [CrossRef]

85. Mohibbe Azam, M.; Waris, A.; Nahar, N.M. Prospects and potential of fatty acid methyl esters of some non-traditional seed oils for use as biodiesel in India. Biomass Bioenergy 2005, 29, 293-302. [CrossRef]

86. Mohammed-Dabo, I.A.; Ahmad, M.S.; Hamza, A.; Muazu, K.; Aliyu, A. Cosolvent transesterification of Jatropha curcas seed oil. J. Pet. Technol. Altern. Fuels 2012, 3, 42-51.

87. Khattab, H.; El, M.Z. Environmental alterations in biofuel generating molecules in Zilla spinosa. Z. Für Naturforschung C 2016, 72, 77-91. [CrossRef] [PubMed]

88. Ashraful, A.M.; Masjuki, H.H.; Kalam, M.A.; Rizwanul Fattah, I.M.; Imtenan, S.; Shahir, S.A.; Mobarak, H.M. Production and comparison of fuel properties, engine performance, and emission characteristics of biodiesel from various non-edible vegetable oils: A review. Energy Convers. Manag. 2014, 80, 202-228. [CrossRef]

89. Ali, E.N.; Tay, C.I. Characterization of Biodiesel Produced from Palm Oil via Base Catalyzed Transesterification. Procedia Eng. 2013, 53, 7-12. [CrossRef]

90. Guil-Laynez, J.L.; Guil-Guerrero, J.L.; Guil-Laynez, Á. Bioprospecting for seed oils in tropical areas for biodiesel production. Ind. Crops Prod. 2019, 128, 504-511. [CrossRef]

91. Karavalakis, G.; Hilari, D.; Givalou, L.; Karonis, D.; Stournas, S. Storage stability and ageing effect of biodiesel blends treated with different antioxidants. Energy 2011, 36, 369-374. [CrossRef]

92. Lin, C.-Y. Blending Biodiesel in Fishing Boat Fuels for Improved Fuel Characteristics. Front. Energy Res. 2014, 2, 1-5. [CrossRef]

93. Akbar, E.; Yaakob, Z.; Kamarudin, S.K.; Ismail, M.; Salimon, J. Characteristic and Composition of Jatropha Curcas Oil Seed from Malaysia and its Potential as Biodiesel Feedstock Feedstock. Eur. J. Sci. Res. 2009, 29, 396-403.

94. Rashid, U.; Anwar, F.; Knothe, G. Evaluation of biodiesel obtained from cottonseed oil. Fuel Process. Technol. 2009, 90, 1157-1163. [CrossRef]

95. Shahabuddin, M.; Kalam, M.A.; Masjuki, H.H.; Bhuiya, M.M.K.; Mofijur, M. An experimental investigation into biodiesel stability by means of oxidation and property determination. Energy 2012, 44, 616-622. [CrossRef]

96. Loh, S.-K.; Chew, S.-M.; Choo, Y.-M. Oxidative stability and storage behavior of fatty acid methyl esters derived from used palm oil. J. Am. Oil Chem. Soc. 2006, 83, 947-952. [CrossRef] 